\title{
Exacerbation of Cerebral Amyloid Angiopathy-Associated Microhemorrhage in Amyloid Precursor Protein Transgenic Mice by Immunotherapy Is Dependent on Antibody Recognition of Deposited Forms of Amyloid $\beta$
}

\author{
Margaret M. Racke, ${ }^{1,2}$ Laura I. Boone, ${ }^{1,3}$ Deena L. Hepburn, ${ }^{1,2}$ Maia Parsadainian, ${ }^{9}$ Matthew T. Bryan, ${ }^{1,2}$ \\ Daniel K. Ness, ${ }^{1,4}$ Kathy S. Piroozi, ${ }^{1,4}$ William H. Jordan, ${ }^{1,3}$ Donna D. Brown, ${ }^{1,4}$ Wherly P. Hoffman, ${ }^{1,5}$ \\ David M. Holtzman, ${ }^{7,8,9,10}$ Kelly R. Bales, ${ }^{1,2}$ Bruce D. Gitter, ${ }^{1,2}$ Patrick C. May, ${ }^{1,2}$ Steven M. Paul, ${ }^{1,6}$ and \\ Ronald B. DeMattos ${ }^{1,2}$ \\ ${ }^{1}$ Lilly Research Laboratories, Eli Lilly and Company, ${ }^{2}$ Neuroscience Discovery Research, Departments of ${ }^{3}$ Pathology, ${ }^{4}$ Toxicology, and ${ }^{5}$ Statistics, Lilly \\ Corporate Center, and ${ }^{6}$ Departments of Pharmacology, Toxicology, and Psychiatry, Indiana University School of Medicine, Indianapolis, Indiana 46285, \\ ${ }^{7}$ Center for the Study of Nervous System Injury, ${ }^{8}$ Alzheimer's Disease Research Center, and Departments of ${ }^{9}$ Neurology and ${ }^{10}$ Molecular Biology and \\ Pharmacology, Washington University School of Medicine, St. Louis, Missouri 63110
}

\begin{abstract}
Passive immunization with an antibody directed against the $\mathrm{N}$ terminus of amyloid $\beta(\mathrm{A} \beta$ ) has recently been reported to exacerbate cerebral amyloid angiopathy (CAA)-related microhemorrhage in a transgenic animal model. Although the mechanism responsible for the deleterious interaction is unclear, a direct binding event may be required. We characterized the binding properties of several monoclonal anti-A $\beta$ antibodies to deposited $\mathrm{A} \beta$ in brain parenchyma and CAA. Biochemical analyses demonstrated that the 3D6 and $10 \mathrm{D} 5$, two N-terminally directed antibodies, bound with high affinity to deposited forms of $\mathrm{A} \beta$, whereas 266 , a central domain antibody, lacked affinity for deposited $\mathrm{A} \beta$. To determine whether 266 or 3D6 would exacerbate CAA-associated microhemorrhage, we treated aged PDAPP mice with either antibody for 6 weeks. We observed an increase in both the incidence and severity of CAA-associated microhemorrhage when PDAPP transgenic mice were treated with the N-terminally directed 3D6 antibody, whereas mice treated with 266 were unaffected. These results may have important implications for future immune-based therapeutic strategies for Alzheimer's disease.
\end{abstract}

Key words: amyloid; CAA; immunotherapy; microhemorrhage; Alzheimer's disease; transgenic

\section{Introduction}

Alzheimer's disease $(\mathrm{AD})$ is a debilitating neurodegenerative disorder that is the most common cause of dementia. The underlying pathologic changes in $\mathrm{AD}$ are the extracellular deposits of the normally soluble amyloid $\beta$ (A $\beta)$ peptide and the intracellular accumulation of neurofibrillary tangles (Selkoe, 2001). Additionally, the majority of AD cases also present with varying degrees of $\mathrm{A} \beta$ deposition in the cerebral vasculature, a condition referred to as cerebral amyloid angiopathy (CAA) (Walker, 1997; Jellinger, 2002; Rensink et al., 2003). The form of $A \beta$ peptide depositing in brain is heterogeneous and dependent on its locale in that parenchymal plaque can be either diffuse or fibrillar (thioflavin S-positive), whereas CAA appears to be primarily fibrillar. These structural differences in $A \beta$ deposits and plaques appear to be related to the type of $\mathrm{A} \beta$ depositing in either location; the major-

Received Oct. 19, 2004; revised Nov. 22, 2004; accepted Nov. 29, 2004.

We thank Robert Dean, Janice Hitchcock, Eric Siemers, Elizabeth Galbreath, and James Kelley for their contributions.

Correspondence should be addressed to Ronald B. DeMattos, Eli Lilly and Company, Neuroscience Discovery Research, Lilly Corporate Center, DC0533, Indianapolis, IN 46285. E-mail: demattos_ronald_bradley@lilly.com. D01:10.1523/JNEUROSCI.4337-04.2005

Copyright $\odot 2005$ Society for Neuroscience $\quad$ 0270-6474/05/250629-08\$15.00/0 ity of $\mathrm{A} \beta$ deposited in parenchyma is $\mathrm{A} \beta_{42}$, whereas CAA is enriched in $\mathrm{A} \beta_{40}$ (Suzuki et al., 1994; Alonzo et al., 1998; McCarron et al., 2000).

The PDAPP mouse, a transgenic mouse line that overexpresses the human mutated form of APP (APP ${ }^{\mathrm{V} 717 \mathrm{~F}}$ ) agedependently develops abundant $\mathrm{A} \beta$ deposition in hippocampal and cortical brain regions (Games et al., 1995; Johnson-Wood et al., 1997). The composition of the deposited parenchymal $A \beta$ in PDAPP mice is quite similar to that observed in sporadic $\mathrm{AD}$ in that it is primarily $\mathrm{A} \beta_{42}$ (Games et al., 1995; Iwatsubo et al., 1996). In contrast, transgenic mice expressing the Swedish mutation (APP $\left.{ }^{\mathrm{K} 670 \mathrm{~N}, \mathrm{M} 671 \mathrm{~L}}\right)$, TG2576 and APP23, develop parenchymal plaques and vessel amyloid that are primarily composed of the $\mathrm{A} \beta_{40}$ peptide (Kawarabayashi et al., 2001; Kuo et al., 2001). The selective enrichment of $\mathrm{A} \beta_{40}$ in the developing lesions in these transgenic mice results in the evolution of significant levels of CAA as well as the related phenomenon of CNS microhemorrhage and occasionally macrohemorrhage (Sturchler-Pierrat et al., 1997; Calhoun et al., 1999; Holtzman et al., 2000; Winkler et al., 2001).

Immunotherapy is a promising new approach that was recently tested in the clinic (Hock et al., 2002, 2003). The active 
immunization clinical trial, however, was terminated because of the development of meningoencephalitis in a number of the patients (Nicoll et al., 2003; Orgogozo et al., 2003; Ferrer et al., 2004). The mechanism responsible for the adverse events is unknown. A recent report by Pfeifer et al. (2002) demonstrated that chronic passive administration with an antibody directed against the $\mathrm{N}$ terminus of the $\mathrm{A} \beta$ peptide in aged APP23 transgenic mice resulted in a twofold increase in the frequency and severity of microhemorrhages (Pfeifer et al., 2002). We sought to investigate the mechanism responsible for the increase in CAA-related microhemorrhage after passive antibody treatment and whether direct antibody binding to the CAA was a requisite for the microhemorrhages. We demonstrate that PDAPP mice age-dependently develop CAA. Antibodies directed against different domains of the $\mathrm{A} \beta$ peptide were shown to have different affinities for deposited $\mathrm{A} \beta$ in both parenchyma and vessels. Finally, chronic administration of the antibodies in aged, CAA-harboring PDAPP mice revealed that exacerbation of microhemorrhage was dependent on antibody binding to deposited $\mathrm{A} \beta$.

\section{Materials and Methods}

Isolation of cerebral vasculature and brain homogenates. Mice were deeply anesthetized with intraperitoneal pentobarbital and transcardially perfused with saline and $0.25 \%$ heparin before removing the brain. Cerebellum and olfactory bulbs were discarded, and brains were weighed and then placed in cold buffer containing (in $\mathrm{mm}$ ): $103 \mathrm{NaCl}, 4.7 \mathrm{KCl}, 2.5$ $\mathrm{CaCl}_{2}, 1.2 \mathrm{KH}_{2} \mathrm{PO}_{4}, 1.2 \mathrm{MgSO}_{4}$, and 15 HEPES, pH 7.4, until all of the brains were harvested. For isolated vessels, each brain was dounce homogenized in $2 \mathrm{ml}$ of cold buffer A (above, plus $25 \mathrm{~mm} \mathrm{NaHCO}_{3}, 10 \mathrm{~mm}$ glucose, $1 \mathrm{~mm}$ pyruvate, and $0.1 \%$ BSA) plus $1 \%$ dextran, and the final volume was brought up to $5 \mathrm{ml}$ with additional buffer A plus $1 \%$ dextran. After adding an equal volume $(5 \mathrm{ml})$ of buffer A plus $31 \%$ dextran, the homogenate was centrifuged at $7000 \mathrm{rpm}$ for $20 \mathrm{~min}$ in the Beckman Instruments (Fullerton, CA) SW40 Ti Ultracentrifuge rotor. The pellet containing the vessels was resuspended in $10 \mathrm{ml}$ of buffer A plus $1 \%$ dextran and passed over a $70 \mu \mathrm{m}$ nylon mesh. The vessels retained on the mesh were washed with an additional $10 \mathrm{ml}$ of buffer A minus the dextran and subsequently harvested from the mesh. For whole-brain homogenate, the tissue was homogenized in $10 \times \mathrm{vol} /$ wet weight $5 \mathrm{~m}$ guanidine and $50 \mathrm{~mm}$ Tris, $\mathrm{pH} 8.0$, and rotated for $6 \mathrm{~h}$ at room temperature. A total of 3-12 transgenic mice of mixed gender were analyzed at multiple ages.

Histological analysis of deposited $A \beta$ by immunohistochemistry and amyloid staining. Formaldehyde-fixed coronal sections $(50 \mu \mathrm{m})$ from 21-month-old PDAPP brains were prepared as described previously (Holtzman et al., 1999). Sections were stained for the presence of amyloid with $0.0125 \%$ thioflavin S (T1892; Sigma, St. Louis, MO) in 50\% ethanol for $6 \mathrm{~min}$. Sections were then rinsed in 50\% ethanol followed by two PBS washes, mounted, and coverslipped with Dako (High Wycombe, UK) fluorescent mounting medium S3023. For $\mathrm{A} \beta$ immunostaining, sections were incubated for $30 \mathrm{~min}$ in a fresh $1 \% \mathrm{H}_{2} \mathrm{O}_{2}$ and $0.3 \%$ Triton $\mathrm{X}-100$ / PBS solution, and $0.65 \%$ sodium azide was applied for an additional 10 min. Sections were rinsed three times in PBS and blocked with $2 \%$ goat serum $/ 0.1 \%$ BSA $/ 0.1 \%$ Triton X-100/PBS for $1 \mathrm{~h}$. Biotinylated anti-A $\beta$ antibodies were diluted in blocking buffer at $3 \mu \mathrm{g} / \mathrm{ml}$ and incubated on sections overnight at $4^{\circ} \mathrm{C}$. After washing in PBS, the sections were developed using the Vector Laboratories (Burlingame, CA) ABC kit per manufacturer's instructions and mounted with Permount. Alzheimer patient brain sections from nonfixed, cryostat-cut tissue were stained in a similar manner. Isolated vessels from a 25-month-old PDAPP mouse were resuspended in PBS plus $0.05 \%$ BSA with $0.000125 \%$ thioflavin S, incubated for $15 \mathrm{~min}$ at room temperature in the dark. Vessels were washed in PBS plus $0.1 \%$ BSA, allowed to dry on a slide, and then coverslipped with Dako fluorescent mounting medium.

In vitro and in vivo association of anti-A $\beta$ antibodies with isolated cerebral vessels. Isolated cerebral vessels from seven 29-month-old female PDAPP mice were pooled and realiquoted for a subsequent incubation in
$3 \mu \mathrm{g} / \mathrm{ml}$ of biotinylated antibodies in PBS ( $n=3$ aliquots per antibody). After $1 \mathrm{~h}$ at room temperature, the vessels were washed three times in PBS, and lysed in $5 \mathrm{~m}$ guanidine $/ 50 \mathrm{~mm}$ Tris, $\mathrm{pH} 8$, with $0.5 \times$ protease inhibitor mixture (1873580; Roche Products, Welwyn Garden City, UK) overnight at $4^{\circ} \mathrm{C}$. Solubilized vessels were used for IgG and A $\beta$ ELISA. To determine whether antibodies will bind to CAA-bearing vessels in vivo, female PDAPP mice ( 25 months of age) were injected intravenously with $100 \mu \mathrm{g}$ of biotinylated antibody (three animals per antibody) and killed $24 \mathrm{~h}$ later. Cerebral vessels were isolated and independently analyzed as described above.

ELISA for IgG and A $\beta$ quantitation. For IgG quantitation, Immulon $4 \mathrm{HBX}$ flat-bottom microtiter plates were coated with $10 \mu \mathrm{g} / \mathrm{ml}$ donkey anti-mouse IgG (Jackson ImmunoResearch, West Grove, PA) overnight at $4^{\circ} \mathrm{C}$. Dilutions of guanidine-lysed vessels with bound biotinylated antibody were incubated on plates in $0.5 \% \mathrm{BSA} / 0.5 \mathrm{~m}$ guanidine $/ 5 \mathrm{~mm}$ Tris/PBS, pH 8.0, overnight at $4^{\circ} \mathrm{C}$. Dilutions of each stock biotinylated antibody were used to generate standard curves. After washing the plate in PBS/0.05\% Tween 20, bound antibody was detected with 1:3000 dilution streptavidin-HRP (RPN1231V; Amersham Biosciences, Arlington Heights, IL). After additional washes in PBS/0.05\% Tween 20, TMB (T8665; Sigma) was added, and the plates were read at $650 \mathrm{~nm}$ in a spectrophotometer. The $\mathrm{A} \beta$ was quantified in guanidine-solubilized extracts from brains and isolated vessels as described previously (DeMattos et al., 2002b).

Histology and cytochemistry of brain sections from aged PDAPP mice given 266 or $3 D 6$ for 6 weeks. We gave 22- to 23-month-old PDAPP mice once weekly intraperitoneal injections of PBS, control IgG1, 266, or 3D6 (all antibodies dosed at $50 \mathrm{mg} / \mathrm{kg}$ ) for a period of 6 weeks. Each treatment group was composed of 16 female and 5 male PDAPP transgenic mice. At the end of the 6 week study, mice were killed, and whole-body perfusion was performed using $10 \%$ neutral-buffered formalin. Preserved brains were trimmed in three coronal sections and embedded in paraffin. All brains were randomly assigned to one of five microtomy schemes differentiated by the number of slices discarded before the first and subsequently collected section. Using this procedure, 20 slices $(6 \mu \mathrm{m})$ containing three sections of brain were collected from each mouse and mounted on glass slides. Perls staining of ferric iron was performed according to a standard protocol. Diaminobenzidine staining to enhance identification of the ferric ferrocyanide product from the Perls stain was conducted using a DAB substrate kit according to the manufacturer's instructions. Two slides, containing three sections of brain, were collected at additional selected intervals in the microtomy scheme and stained with hematoxylin and eosin (H\&E) according to a standard protocol.

Generation of mean severity index of hemosiderin staining in the meninges. Eight evenly distributed slides (containing a total of 24 brain sections) were evaluated and assigned a qualitative grade based on the estimated number of DAB-enhanced Perls stain-positive (DAB-EP) cells in the meninges for each section. All observations of DAB-EP staining in the meninges for each mouse were tallied by qualitative grade [no staining (NS), minimal (MI), slight (SL), and moderate (MO)]. Qualitative grades were assigned severity scores of $\mathrm{NS}=0, \mathrm{MI}=1, \mathrm{SL}=2$, and $\mathrm{MO}=3$. The individual severity index for meninges for each mouse was generated according to the following formula: $\left(A^{\star} 0\right)+\left(B^{\star} 1\right)+\left(C^{\star}\right.$ $2)+\left(D^{\star} 3\right) / N$; where $A, B, C$, and $D=$ tallied observations of NS, MI, SL, and $\mathrm{MO}$, respectively, and $N=$ total number of DAB-EP observations per meninges per mouse.

The mean severity index for meninges was then calculated for each treatment group. The mean of each group given 266 or 3D6 was compared with the mean of the IgG1 control group using Dunnett's $t$ test (Dunnett, 1964) at the 0.05 significance level. Shapiro-Wilk's test (Shapiro and Wilk, 1965) for normality and Levene's test (Levene, 1960) for homogeneity of variance were performed at the 0.01 significance level. When either of the diagnostic tests was significant, statistical inferences were based on analysis of appropriately transformed data, along with heterogeneous variances when necessary. Severity indices from the meninges were modeled with heterogeneous variances. 
A

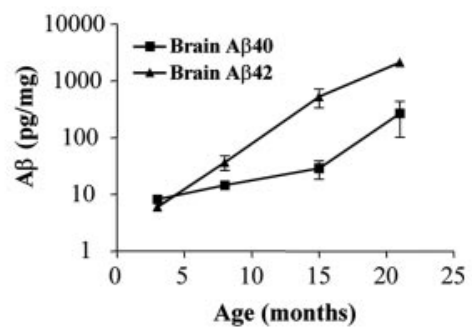

C

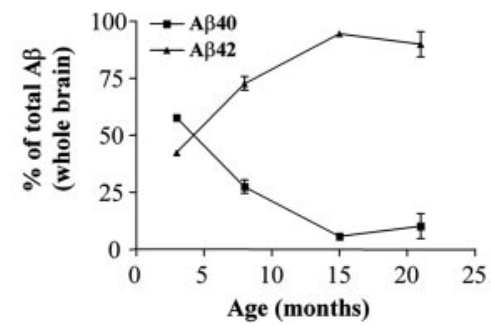

B

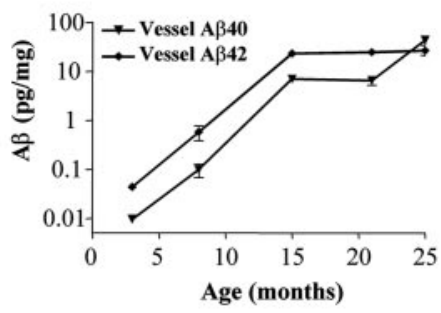

D

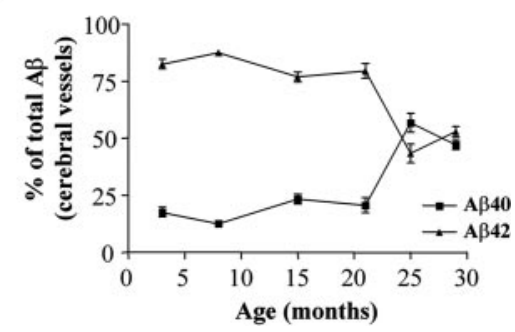

Figure 1. $A \beta_{42}: A \beta_{40}$ ratio varies with age in brain and cerebral vessels. Accumulation of $A \beta$ peptides in whole brain or isolated microvessels from PDAPP mice was measured by ELISA at multiple ages (3-12 mice per group; error bars represent SE). The data are presented as picograms of $A \beta$ per milligram of wet weight of brain $(A)$ or vessels $(B)$. Data demonstrate robust accumulation of $A \beta_{42}$ in parenchyma $(A)$ with up to $95 \%$ total $A \beta$ being $1-42$ by 15 months $(C)$. In contrast, isolated vessels with $C A A(B, D)$ show selective enrichment of $A \beta_{40}$, resulting in equivalent amounts of both species by 25 months $(D)$.

\section{Results}

\section{Characterization of CAA in PDAPP transgenic mice}

Previous studies in PDAPP transgenic mice have shown an agedependent accumulation of the $\mathrm{A} \beta$ peptide in brain parenchyma (Games et al., 1995; Johnson-Wood et al., 1997). To determine whether a similar age-dependent accumulation of $\mathrm{A} \beta$ peptide occurs in cerebral microvessels, we performed an extensive biochemical characterization of whole brain and isolated cerebral microvessels over a wide range of ages in PDAPP mice. ELISA analysis of whole brain (parenchyma and vessels) showed a dramatic increase in the levels of $A \beta_{42}(\sim 250$-fold $)$ and a modest increase in the levels of $A \beta_{40}(\sim 25$-fold) (Fig. $1 A)$. Young predepositing PDAPP mice have almost equivalent levels of $\mathrm{A} \beta_{40}$ and $\mathrm{A} \beta_{42}$ in brain. However, as the mice begin to deposit $\mathrm{A} \beta$ in the parenchyma, the overall percentage of $\mathrm{A} \beta$ peptide becomes enriched in $A \beta_{42}$, which appears to plateau at $\sim 90 \%$ of total $A \beta$ between 15 and 21 months of age (Fig. $1 C$ ). Similar to the overall brain accumulation of $A \beta$, there is a dramatic increase in the levels of both $A \beta_{40}$ and $A \beta_{42}$ in isolated cerebral microvessels (Fig. $1 B$ ). Importantly, and in contrast to the whole brain, the percentage of $\mathrm{A} \beta_{40}$ becomes enriched in vessels $(\sim 50 \%)$ relative to the parenchyma $(\sim 10 \%)$ between 21 and 29 months of age (Fig. 1C,D). Enhanced deposition of $\mathrm{A} \beta_{40}$ in cerebral vessels has been demonstrated to be a molecular marker for the presence of CAA in AD and transgenic animals (Suzuki et al., 1994; Alonzo et al., 1998; McCarron et al., 2000).

We then investigated whether we could visualize CAA in 21to 25-month-old PDAPP mice. Thioflavin S staining of PDAPP brain sections showed significant parenchymal amyloid pathology throughout the hippocampal and cortical regions (Fig. 2A). Well defined CAA was only readily detectible in the leptomeninges where the typical concentric pattern was observed (Fig. $2 B$ ). To increase the sensitivity of the detection of amyloid, cerebral microvessels were isolated and subsequently stained with thioflavin S. Phase-contrast imaging of the isolated vessels demon-

strated that well defined vessels survived the isolation procedure and were free of cellular debris (Fig. 2C). Surprisingly, a large proportion of vessels had thioflavin S-positive amyloid associated with them (Fig. 2D-F). Higher magnification showed that the amyloid was bound as globular clumps on the brain parenchymal side of the vessels (Fig. $2 F$ ). Interestingly, the vast majority of vessels that were thioflavin S-positive did not have regions that were completely encircled by the deposited material. It is highly likely that this form of CAA would be extremely difficult to identify in brain sections, because without the concentric pattern the amyloid would be assumed simply to be in the parenchyma. These findings, in conjunction with the A $\beta$ ELISA measurements, demonstrate that PDAPP transgenic mice do develop significant age-related CAA and that the $\mathrm{A} \beta$ peptide ratios are quite similar to those observed in patients with sporadic AD (Alonzo et al., 1998).

\section{In vitro and in vivo binding characteristics of anti-A $\beta$ antibodies to deposited forms of $A \boldsymbol{\beta}$}

Antibodies directed against different epitopes within the $\mathrm{A} \beta$ sequence can also have varying affinities for either soluble or deposited forms of $\mathrm{A} \beta$. We investigated the binding properties of antibodies that are directed against the $\mathrm{N}$-terminal domain (3D6, amino acids $1-5 ; 10 \mathrm{D} 5$, amino acids $3-6)$, the central domain (266, amino acids 13-28), or an irrelevant murine IgG. Immunohistochemistry was performed on fixed brain sections from aged PDAPP transgenic mice (Fig. 3) or nonfixed human AD brain sections (Fig. 4). The N-terminally directed antibodies 3D6 and $10 \mathrm{D} 5$ robustly labeled deposited forms of $\mathrm{A} \beta$ in both PDAPP and human $\mathrm{AD}$ brain sections. In contrast, the central domain antibody 266 did not bind to the deposited $A \beta$ in these studies and was found to be indistinguishable from controls (irrelevant IgG, no primary antibody). These results demonstrate that antibodies directed against different regions and/or conformations of the $\mathrm{A} \beta$ peptide possess varying abilities to recognize their epitope when the $\mathrm{A} \beta$ peptide is in a deposited form, a result likely caused by an altered secondary structure of the peptide.

Because the structure of the $\mathrm{A} \beta$ peptide may be different depending on whether it is deposited in parenchyma or in vessels, we then investigated the antibody binding affinities for CAA. Microvessels harboring CAA were isolated and pooled from a cohort of 29-month-old PDAPP mice. Under physiological conditions, the antibodies were incubated with aliquots of the isolated vessels, and the amount of specifically bound antibody was determined. The N-terminally directed antibodies 3D6 and 10D5 both bound to the CAA associated with the microvessels significantly better than did the control IgG (Fig. 5A). The central domain antibody 266 did not associate with the CAA-bearing vessels, although there was equivalent amount of $\mathrm{A} \beta$ present (Fig. $5 A, B)$. When normalized to the percentage of 266 binding, it was shown that 3D6 and 10D5 bound 112- and 52-fold better than 266 , respectively. The IgG control antibody also bound to a slightly higher degree than 266, perhaps demonstrating the inherent "stickiness" of CAA and subtle differences that antibodies 

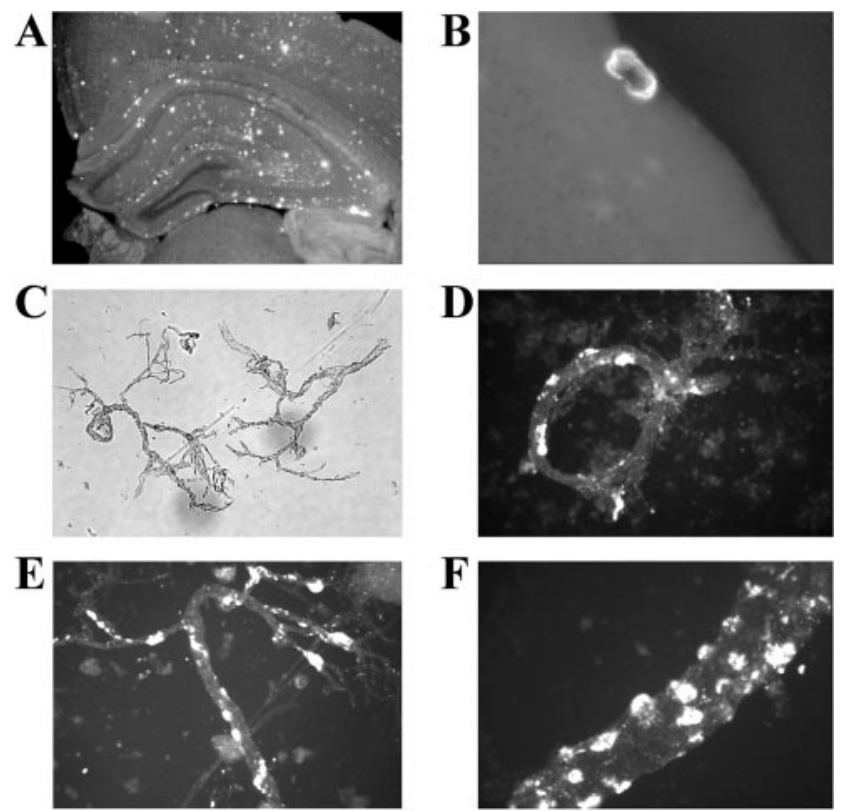

Figure 2. Thioflavin $S$ staining of brain sections and cerebral vessels to identify amyloid deposits. Thioflavin $S$ staining of $50 \mu \mathrm{m}$ floating sections from a 21-month-old PDAPP mouse brain $(A, B)$ and isolated cerebral vessels from a 25-month-old PDAPP mouse $(C-F)$ is shown. Note the areas of intense thioflavin $S$ staining (yellow color) in the isolated vessels that appear to be localized on the outside of the vessels (brain side) $(D-F) . C, A 40 \times$ bright-field view of isolated vessels demonstrating the integrity of the vessel preparation.
A

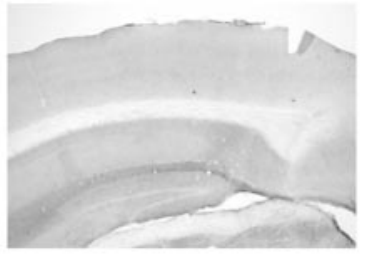

C

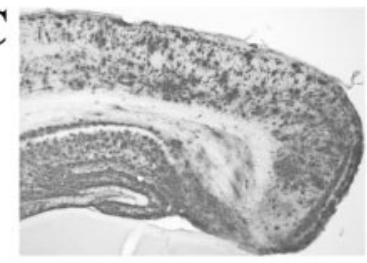

$\mathbf{E}$

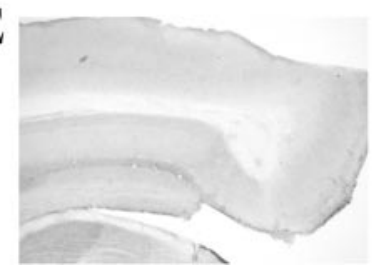

B

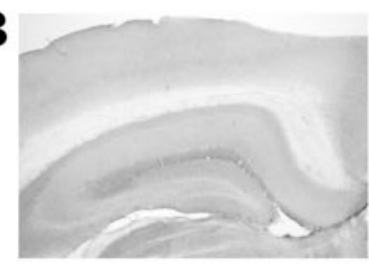

D

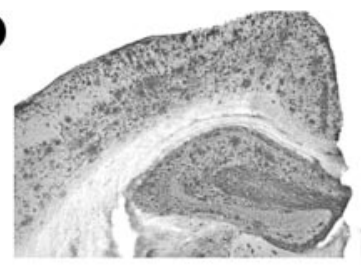

Figure 3. Antibody affinity for deposited $A \beta$ by immunostaining in PDAPP sections. Immunostaining was performed on formalin-fixed brain sections from a 21-month-old PDAPP mouse. Nterminal domain antibodies 3D6 $(C$ and 10D5 $(D)$ were able to bind deposited $A \beta$, whereas middomain antibody $266(E)$ was indistinguishable from biotinylated isotype control $(B)$ or no primary antibody $(A)$. Floating sections were stained with biotinylated antibodies at a concentration of 3.0 $\mu \mathrm{g} / \mathrm{ml}$. Levels of biotinylation were similar among all antibodies (data not shown).

have for nonspecific binding to amyloid. All of the above antibodies lacked any appreciable binding when incubated with microvessels obtained from young PDAPP mice lacking deposited $\mathrm{A} \beta$ (data not shown).
A

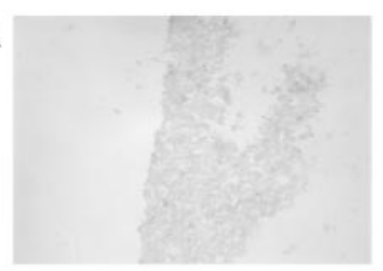

B

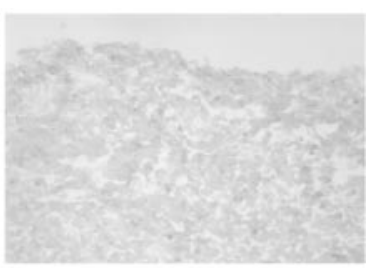

C

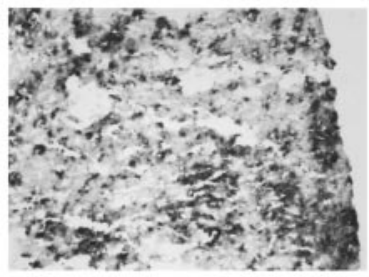

D

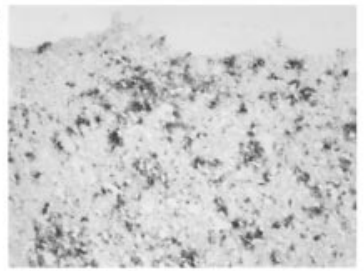

$\mathbf{E}$

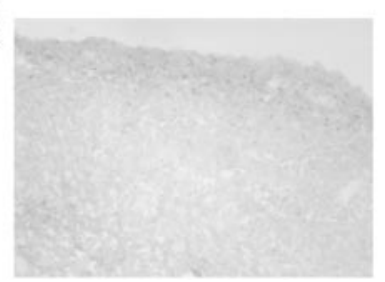

Figure 4. Antibody affinity for deposited $A \beta$ by immunostaining in human Alzheimer brain sections. Immunostaining was performed on nonfixed cryostat-cut brain sections from an $\mathrm{Alz}$ heimer brain. Sections were stained with the biotinylated antibodies at a concentration of 3.0 $\mu \mathrm{g} / \mathrm{ml}$. N-terminal domain antibodies 3D6 (C) and 10D5 (D) were able to bind deposited A $\beta$, whereas mid-domain antibody $266(E)$ was indistinguishable from biotinylated isotype control $(B)$ or no primary antibody $(A)$.

Although the preceding results demonstrate selective binding properties of anti-A $\beta$ antibodies to CAA in vitro, it was unclear whether these properties would translate to the in vivo situation because of the complexities imposed by the blood-brain barrier (BBB). However, it is likely that an antibody passively diffusing across the BBB would first be expected to interact with CAA as opposed to parenchymal $A \beta$. To test whether peripherally administered antibody crosses the BBB and binds to CAA, we intravenously injected the antibodies and subsequently isolated microvessels under nondenaturing conditions $24 \mathrm{~h}$ later. We observed a striking similarity between the in vitro and in vivo results (Fig. 6). The $\mathrm{N}$-terminally directed anti-A $\beta$ antibodies were easily detected in the isolated microvessels, with the accumulation of 3D6 being approximately fivefold higher than for 10D5. Both 266, the central domain antibody, and the irrelevant IgG control antibody were barely detectable in the isolated vessels, and in fact were below the lowest assay standard. These results demonstrate that the $\mathrm{N}$-terminally directed antibodies have the potential to bind and localize to amyloid within the vessel and possibly exacerbate amyloid-mediated vascular degeneration, whereas the central domain antibody 266 lacks the potential to localize to these sites of vessel amyloid.

\section{Exacerbation of CAA-related microhemorrhage by anti-A $\beta$ antibodies that bind deposited $\mathrm{A} \boldsymbol{\beta}$}

A study was conducted to determine whether 266 or 3D6 would facilitate CAA-associated microhemorrhage in aged (22- to 23month-old) PDAPP mice when given once weekly for a period of 6 weeks. Doses of 0 (vehicle control, physiological buffered saline) or $50 \mathrm{mg} / \mathrm{kg} 266$ were given intraperitoneally to male and female aged PDAPP mice ( $n=21$ /group). Additionally, PDAPP 
A

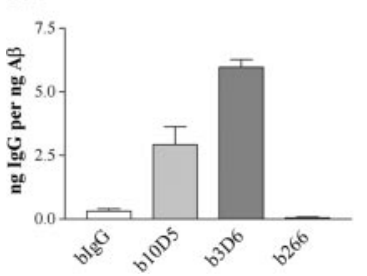

C

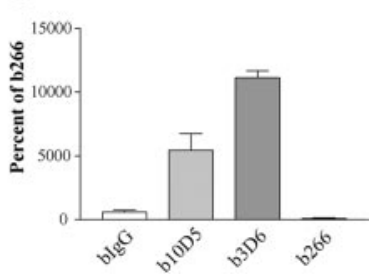

Figure 5. Anti-A $\beta$ antibody affinity for CAA in vitro. Microvessels were isolated and pooled from 29-month-old PDAPP mice. Aliquots of vessels were incubated with the biotinylated antibodies under physiological conditions. $A$, ELISAs specific for biotinylated (b) antibodies show that 10D5 and 3D6, two N-terminal antibodies, bound with high affinity to the amyloid bearing vessels, whereas 266, a mid-domain anti-A $\beta$ antibody, lacked specific binding and was similar to the lgG control. $B, A \beta$ ELISA demonstrated that equivalent levels of amyloid were present in the vessel aliquots among the different treatments. $C$, Normalized to the biotinylated 266 values, the N-terminal antibodies b10D5 and b3D6 bound to the amyloid bearing vessels $\sim 50$ - and 100-fold higher, respectively.

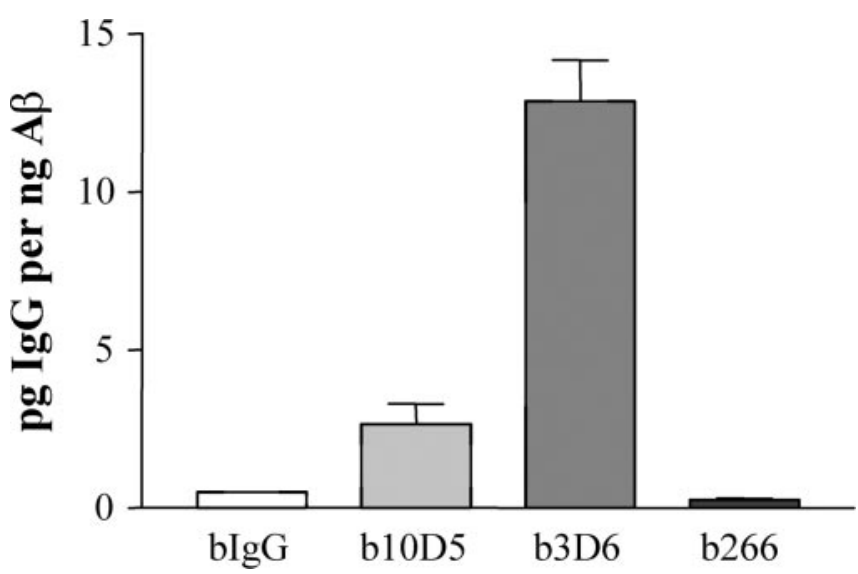

Figure 6. Anti-A $\beta$ antibody affinity for CAA in vivo. To test whether antibodies will cross the BBB and bind to CAA-bearing vessels in vivo, PDAPP mice (25 months of age) were injected intravenously with $100 \mu \mathrm{g}$ of biotinylated (b) antibody and killed $24 \mathrm{~h}$ later. Cerebral vessels were isolated and independently analyzed for the accumulation of biotinylated antibodies ( 3 animals per antibody). Similar to the in vitro analyses, the biotinylated 3D6 accumulated to a larger degree than the other $\mathrm{N}$-terminally directed antibody, 10D5. The levels of 266 and control $\lg G$ were below the level of detection for the assay.

mice in separate antibody control groups were given $50 \mathrm{mg} / \mathrm{kg}$ of either IgG1 (IgG control) or the N-terminally directed comparator antibody $3 \mathrm{D} 6$.

No acute hemorrhages were evident in the neocortex, brainstem, or cerebellum of mice given $50 \mathrm{mg} / \mathrm{kg} 266$. Additionally, the incidence and mean severity index of DAB-EP, a histological assessment indicative of microhemorrhages, were similar in the neocortex of mice given PBS or IgG1 (negative controls) (Fig. 7A) and $50 \mathrm{mg} / \mathrm{kg} 266$.

In contrast, mice given the N-terminally directed antibody 3D6 exhibited increases in microhemorrhages, as indicated by an increase in the incidence and magnitude of DAB-EP staining that was most pronounced in the meninges (Fig. $7 B$ ), generally diffusely perivascular in orientation, and often extending into the adjacent neocortex (Fig. 7D,E). The perivascular distribution of the microhemorrhages in the meninges and adjacent neocortex of 3D6-treated mice, indicated by DAB-EP staining, was consistent with the distribution of CAA reported in humans (Walker, 1997), other transgenic mouse models (Winkler et al., 2001), and this PDAPP mouse model (Backsai et al., 2001; Fryer et al., 2003). Additionally, the mean severity index of DAB-EP staining in the meninges was significantly increased (approximately twofold) compared with the IgG1-treated controls (Fig. 8).

Acute focal macrohemorrhages, indicated by extravascular accumulations of erythrocytes, occurred in three female 3D6-treated mice. Concurrent accumulations of cells with intracellular hemosiderin, as evidenced by DAB-EP staining, indicated recurrent hemorrhage at those sites. Two 3D6-treated female mice had extensive focal hemorrhage in the cerebral cortex and/or midbrain (Fig. 7C,F); the remaining affected mouse had bilateral hemorrhages in the cerebral cortex and adjacent meninges (Fig. 7G,H). Our findings of acute hemorrhages and increased incidence and severity of microhemorrhages in the 3D6-treated PDAPP mice were consistent with the study by Pfeifer et al. (2002) that reported increased CAA-associated microhemorrhage using another antibody targeting the $\mathrm{N}$-terminal sequence of $\mathrm{A} \beta$, a different transgenic mouse model, and a longer duration of exposure.

\section{Discussion}

We investigated the mechanisms of anti-A $\beta$ antibody-dependent increases in the frequency and severity of CAA-associated microhemorrhage. The PDAPP transgenic mouse model was shown to age-dependently develop extensive $\mathrm{A} \beta$ deposition within the cerebral vessels. At ages of $>21$ months, there was a dramatic shift in the ratio of $\mathrm{A} \beta_{42}$ to $\mathrm{A} \beta_{40}$, a hallmark biochemical feature that signifies the development of CAA. Characterization of a panel of monoclonal antibodies directed against different domains of the $\mathrm{A} \beta$ peptide revealed selective binding preferences that were dependent on the aggregation state of the peptide (deposited vs soluble). The $\mathrm{N}$-terminal antibodies 3D6 and 10D5 were able to bind to their epitopes in the $\mathrm{A} \beta$ peptide regardless of the aggregation state. These antibodies bound to deposited $\mathrm{A} \beta$ in tissue sections and in CAA-bearing vessels (in vitro and in vivo). In contrast, the central domain antibody 266 was shown to lack any binding to the deposited forms of the $\mathrm{A} \beta$ peptide. Coupled with our previous observation that 266 binds with high affinity to soluble $\mathrm{A} \beta$ (DeMattos et al., 2001), these results demonstrate that 266 is a conformation-specific antibody that solely recognizes soluble A $\beta$. Finally, we show that after 6 weeks of passive administration of the antibodies into aged PDAPP transgenic mice, only the N-terminally directed antibody (3D6) binds to deposited A $\beta$ in CAA and leads to an increased incidence and severity of microhemorrhage.

The recent report by Pfeifer et al. (2002) showed that immunotherapy in aged APP23 transgenic mice with an antibody directed against the $\mathrm{N}$-terminal domain significantly increased the incidence and severity of CAA-associated microhemorrhage (Pfeifer et al., 2002). Because of the design of the study and use of a monoclonal $\mathrm{A} \beta$ antibody, a T-cell-mediated response can all but be eliminated as the cause of the increase in CAA-associated microhemorrhage. However, several important questions, including what mechanism caused the antibodies to exacerbate the CAA-associated microhemorrhage, and whether a similar effect would occur in a transgenic mouse model of AD not characterized by sporadic hemorrhagic stroke, were not addressed. APP23 transgenic mice overexpress APP bearing the Swedish mutation, and as a result, develop AD-like histological changes in brain parenchyma and microvessels that are primarily composed of $\mathrm{A} \beta_{40}$ (Sturchler-Pierrat et al., 1997; Calhoun et al., 1999). Al- 
though APP23 mice mimic the pattern of amyloid deposition seen in patients harboring the Swedish mutation, it is not representative of the deposition in the majority of $\mathrm{AD}$ cases wherein $\mathrm{A} \beta_{42}$ is the predominant depositing peptide (Iwatsubo et al., 1996). In contrast, the PDAPP transgenic mouse has been shown to manifest $A \beta$ deposition and amyloid pathology that is quite similar to that observed in sporadic AD (Games et al., 1995; Iwatsubo et al., 1996; Johnson-Wood et al., 1997). Additionally, our current findings demonstrate age-dependent microvessel accumulation of $A \beta$ peptides and the presence of $\mathrm{A} \beta_{42}: \mathrm{A} \beta_{40}$ ratios that are similar to those observed in human CAA (Suzuki et al., 1994; Alonzo et al., 1998; McCarron et al., 2000). Similar to the results obtained by Pfeifer et al. (2002), we observed a twofold increase in the incidence and severity of CAA-associated microhemorrhages in animals passively administered an antibody directed against the $\mathrm{N}$ terminus of $\mathrm{A} \beta$. Moreover, we observed microhemorrhages after only 6 weeks of passive immunotherapy, a treatment duration that was four times shorter than that used in the Pfeifer study. This suggests that the fundamental prerequisite for these microhemorrhages is the presence of CAA and therefore may be applicable to any $\mathrm{AD}$ population that manifests significant levels of CAA. Our results support previous findings that an $\mathrm{N}$-terminally directed antibody could exacerbate CAA and result in increased microhemorrhage.

The central domain anti-A $\beta$ antibody 266 did not lead to an increased frequency or severity of microhemorrhage, a result that provides important insight into the mechanism responsible for the increased microhemorrhage. The fundamental difference between the $\mathrm{N}$-terminally directed antibodies that led to increased microhemorrhage and 266 is their ability to bind specifically to deposited forms of $A \beta$. Although 266 binds readily to soluble monomeric A $\beta$ (DeMattos et al., 2001, 2002a), we have demonstrated that 266 does not bind to deposited $A \beta$ in either brain parenchyma or cerebral vessels. We have proposed that the mechanism of action for 266 in reducing $A \beta$ deposition in the brain is the binding of soluble $A \beta$, thereby shifting the equilibrium in favor of CNS to peripheral clearance of $\mathrm{A} \beta$ (DeMattos et al., 2001). A future study that would solidify the direct binding hypothesis should compare microhemorrhage after chronic administration of 266 or $4 \mathrm{G} 8$, a central domain antibody that binds to deposited $\mathrm{A} \beta$. The $\mathrm{N}$-terminally directed antibody $3 \mathrm{D} 6$, as well as the majority of antibodies generated via active immunization, bind readily to all deposited forms of $\mathrm{A} \beta$ (Bard et al., 2000, 2003; McLaurin et al., 2002); indeed, direct binding is a required step for the proposed microglial Fc-mediated clearance of A $\beta$ deposits (Schenk et al., 1999; Bard et al., 2000). Interestingly, a recent report demonstrated that a C-terminally directed antibody that recognizes deposited $\mathrm{A} \beta_{40}$ yielded a similar increase in microhemorrhage (Wilcock et al., 2004).

Although the degree of CAA is quite variable, its prevalence in confirmed $\mathrm{AD}$ patients is quite high and is observed in $80-90 \%$ of patients at autopsy (Jellinger, 2002; Rensink et al., 2003). A re-

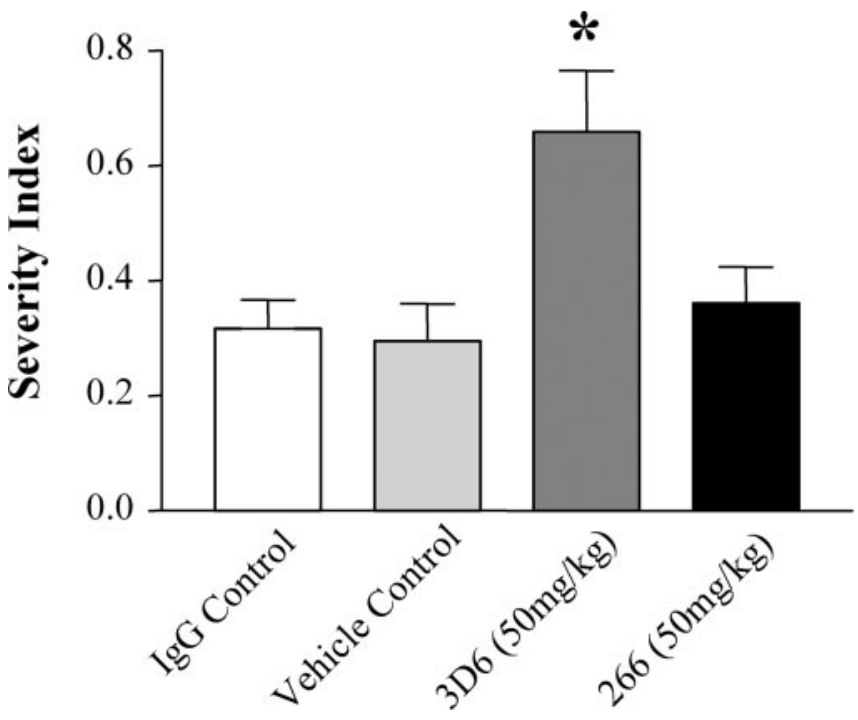

Figure 8. Mean severity index of hemosiderin staining in the meninges. Mean severity index of hemosiderin staining in the meninges indicated an approximately twofold increase in 3D6treated mice compared with lgG-treated control mice $\left({ }^{*} p<0.05\right)$.

lated feature of CAA pathology is degeneration of cellular components of the vessel wall and chronic inflammation (Vinters, 1987; Frackowiak et al., 1994; Anders et al., 1997; Grammas and Ovase, 2001; Van Nostrand et al., 2002; Eng et al., 2004; Oh et al., 2004). Characterization of microvessels isolated from AD patients has shown a significant increase in the release of the proinflammatory cytokines interleukin- $1 \beta$ (IL-1 $\beta$ ), IL-6, and tumor necrosis factor- $\alpha$ compared with control microvessels (Grammas 
and Ovase, 2001). Additionally, two recent reports demonstrated that, in a subset of patients, an infiltration of multinucleated white blood cells and the presence of recurrent microhemorrhages were associated with CAA-bearing vessels (Eng et al., 2004; Oh et al., 2004). In both reports, the patients presented with subacute cognitive decline that was responsive to immunosuppressive therapy.

In January of 2002, Elan Pharmaceuticals halted their active vaccination trials because of the occurrence of adverse events in a subset of patients (Nicoll et al., 2003; Orgogozo et al., 2003; Ferrer et al., 2004). A low percentage of patients who had received intramuscular injections of AN1792, $225 \mu$ g of preaggregated $A \beta_{42}$, along with an immunogenic adjuvant, developed clinical symptoms consistent with aseptic meningoencephalitis. Although the mechanism responsible for the neuroinflammation is poorly understood, it has been suggested that a primary cause may have been the infiltration of autoreactive T-lymphocytes into the brain in response to the active immunization (Nicoll et al., 2003; Orgogozo et al., 2003; Ferrer et al., 2004). It is noteworthy that an autopsy on one of the encephalitic patients from the active immunization trial revealed both inflammatory infiltrates and the presence of severe small cerebral blood vessel disease and multiple cortical hemorrhages (Ferrer et al., 2004). It was also noted that an obvious relationship existed between the presence of CSF $\mathrm{A} \beta$ antibodies and the risk of encephalitis, although serum titers showed no apparent correlation (Orgogozo et al., 2003). Characterization of the serum antibodies demonstrated selective recognition of aggregated $\mathrm{A} \beta$ in parenchymal and cerebral vessels (Hock et al., 2002). Additionally, it has been shown in monkey and transgenic mouse studies that the predominant antibody response via active immunization is reactive to epitopes found in the N-terminal domain of A $\beta$ (McLaurin et al., 2002; Spooner et al., 2002; Lemere et al., 2004). Indeed, the antibodies generated via active immunization appear to be quite similar to the $\mathrm{N}$-terminal antibodies used in the current study. What currently is unclear, however, is whether these observations in transgenic mice will translate into possible adverse events in the clinic. Additional studies are needed to investigate the inflammatory cascade that ensues when the anti-A $\beta$ antibodies bind to the CAA.

\section{References}

Alonzo NC, Hyman BT, Rebeck GW, Greenberg SM (1998) Progression of cerebral amyloid angiopathy: accumulation of amyloid-beta 40 in affected vessels. J Neuropathol Exp Neurol 57:353-359.

Anders KH, Wang ZZ, Kornfeld M, Gray F, Soontornniyomkij V, Reed LA, Hart MN, Menchine M, Secor DL, Vinters HV (1997) Giant cell arteritis in association with cerebral amyloid angiopathy: immunohistochemical and molecular studies. Hum Pathol 28:1237-1246.

Backsai BJ, Kajdasz ST, Christie RH, Carter C, Games D, Seubert P, Schenk D, Hyman BT (2001) Imaging of amyloid- $\beta$ deposits in brains of living mice permits direct observation of clearance of plaques with immunotherapy. Nat Med 7:369-372.

Bard F, Cannon C, Barbour R, Burke RL, Games D, Grajeda H, Guido T, Hu K, Huang J, Johnson-Wood K, Khan K, Kholodenko D, Lee M, Lieberburg I, Motter R, Nguyen M, Soriano F, Vasquez N, Weiss K, Welch B, et al. (2000) Peripherally administered antibodies against amyloid $\beta$-peptide enter the central nervous system and reduce pathology in a mouse model of Alzheimer's disease. Nat Med 6:916-919.

Bard F, Barbour R, Cannon C, Carretto R, Fox M, Games D, Guido T, Hoenow K, Hu K, Johnson-Wood KL, Khan K, Kholodenko D, Lee M, Motter R, Nguyen M, Reed A, Schenk D, Tang P, Vasquez N, Seubert P, et al. (2003) Epitope and isotype specificities of antibodies to $\beta$-amyloid peptide for protection against Alzheimer's disease-like neuropathology. Proc Natl Acad Sci USA 100:2023-2028.

Calhoun ME, Burgermeister P, Phinney AL, Stalder M, Tolnay M, Wiederhold K-H, Abramowski D, Sturchler-Pierrat C, Sommer B, Staufenbiel M,
Jucker M (1999) Neuronal overexpression of mutant amyloid precursor protein results in prominent deposition of cerebrovascular amyloid. Proc Natl Acad Sci USA 96:14088-14093.

DeMattos RB, Bales KR, Cummins DJ, Dodart J-C, Paul SM, Holtzman DM (2001) Peripheral anti-A $\beta$ antibody alters CNS and plasma $A \beta$ clearance and decreases brain $\mathrm{A} \beta$ burden in a mouse model of Alzheimer's disease. Proc Natl Acad Sci USA 98:8850-8855.

DeMattos RB, Bales K, Cummins DJ, Paul SM, Holtzman DM (2002a) Brain to plasma amyloid-beta efflux: a measure of brain amyloid burden in a mouse model of Alzheimer's disease. Science 295:2264-2267.

DeMattos RB, O’Dell MA, Parsadanian M, Taylor JW, Harmony JA, Bales KR, Paul SM, Aronow BJ, Holtzman DM (2002b) Clusterin promotes amyloid plaque formation and is critical for neuritic toxicity in a mouse model of Alzheimer's disease. Proc Natl Acad Sci USA 99:10843-10848.

Dunnett CW (1964) New tables for multiple comparisons with a control. Biometrics 20:482-491.

Eng JA, Frosch MP, Choi K, Rebeck GW, Greenberg SM (2004) Clinical manifestations of cerebral amyloid angiopathy-related inflammation. Ann Neurol 55:250-256.

Ferrer I, Boada Rovira M, Sanchez Guerra ML, Rey MJ, Costa-Jussa F (2004) Neuropathology and pathogenesis of encephalitis following amyloid-beta immunization in Alzheimer's disease. Brain Pathol 14:11-20.

Frackowiak J, Zoltowska A, Wisniewski HM (1994) Non-fibrillar betaamyloid protein is associated with smooth muscle cells of vessel walls in Alzheimer disease. J Neuropathol Exp Neurol 53:637-645.

Fryer JD, Taylor JW, DeMattos RB, Bales KR, Paul SM, Parsadanian M, Holtzman DM (2003) Apolipoprotein E markedly facilitates agedependent cerebral amyloid angiopathy and spontaneous hemorrhage in amyloid precursor protein transgenic mice. J Neurosci 23:7889-7896.

Games D, Adams D, Alessandrini R, Barbour R, Berthelette P, Blackwell C, Carr T, Clemens J, Donaldson T, Gillespie F, Guido T, Hagopian S, Johnson-Wood K, Khan K, Lee M, Leibowitz P, Lieberburg I, Little S, Masliah E, McConlogue L, et al. (1995) Alzheimer-type neuropathology in transgenic mice overexpressing V717F $\beta$-amyloid precursor protein. Nature 373:523-527.

Grammas P, Ovase R (2001) Inflammatory factors are elevated in brain microvessels in Alzheimer's disease. Neurobiol Aging 22:837-842.

Hock C, Konietzko U, Papassotiropoulos A, Wollmer MA, Streffer J, von Rotz RC, Davey G, Moritz E, Nitsch RM (2002) Generation of antibodies specific for $\beta$-amyloid by vaccination of patients with Alzheimer's disease. Nat Med 8:1270-1275.

Hock C, Konietzko U, Streffer JR, Tracy J, Signorell A, Muller-Tillmanns B, Lemke U, Henke K, Moritz E, Garcia E, Wollmer MA, Umbricht D, deq Uervain DJ, Hofmann M, Maddalena A, Papassotiropoulos A, Nitsch RM (2003) Antibodies against beta-amyloid slow cognitive decline in Alzheimer's disease. Neuron 38:547-554.

Holtzman DM, Bales KR, Wu S, Bhat P, Parsadanian M, Fagan AM, Chang LK, Sun Y, Paul SM (1999) In vivo expression of apolipoprotein E reduces amyloid- $\beta$ deposition in a mouse model of Alzheimers disease. J Clin Invest 103:R15-R21.

Holtzman DM, Fagan AM, Mackey B, Tenkova T, Sartorius L, Paul SM, Bales K, Ashe KH, Irizzary MC, Hyman BT (2000) ApoE facilitates neuritic and cerebrovascular plaque formation in the APPsw mouse model of Alzheimer's disease. Ann Neurol 47:739-747.

Iwatsubo T, Saido TC, Mann DM, Lee VM, Trojanowski JQ (1996) Fulllength amyloid-beta $(1-42(43))$ and amino-terminally modified and truncated amyloid-beta 42(43) deposit in diffuse plaques. Am J Pathol 149:1823-1830

Jellinger KA (2002) Alzheimer disease and cerebrovascular pathology: an update. J Neural Transm 109:813-836.

Johnson-Wood K, Lee M, Motter R, Hu K, Gordon G, Barbour R, Khan K, Gordon M, Tan H, Games D, Lieberburg I, Schenk D, Seubert P, McConlogue L (1997) Amyloid precursor protein processing and A $\beta 42$ deposition in a transgenic mouse model of Alzheimer's disease. Proc Natl Acad Sci USA 94:1550-1555.

Kawarabayashi T, Younkin LH, Saido TC, Shoji M, Ashe KH, Younkin SG (2001) Age-dependent changes in brain, CSF, and plasma amyloid $\beta$ protein in the Tg2576 transgenic mouse model of Alzheimer's disease. J Neurosci 21:372-381.

Kuo YM, Kokjohn TA, Beach TG, Sue LI, Brune D, Lopez JC, Kalback WM, Abramowski D, Sturchler-Pierrat C, Staufenbiel M, Roher AE (2001) Comparative analysis of amyloid-beta chemical structure and amyloid 
plaque morphology of transgenic mouse and Alzheimer's disease brains. J Biol Chem 276:12991-12998.

Lemere CA, Beierschmitt A, Iglesias M, Spooner ET, Bloom JK, Leverone JF, Zheng JB, Seabrook TJ, Louard D, Li D, Selkoe DJ, Palmour RM, Ervin FR (2004) Alzheimer's disease abeta vaccine reduces central nervous system abeta levels in a non-human primate, the Caribbean vervet. Am J Pathol 165:283-297.

Levene H (1960) Robust tests for equality of variances. In: Contributions to probability and statistics (Olkin I, Ghurye SG, Hoeffding W, Madow WG, Mann HB, eds), pp 278-292. Stanford, CA: Stanford UP.

McCarron MO, Nicoll JA, Stewart J, Cole GM, Yang F, Ironside JW, Mann DM, Love S, Graham DI (2000) Amyloid beta-protein length and cerebral amyloid angiopathy-related haemorrhage. NeuroReport 11:937-940.

McLaurin J, Cecal R, Kierstead ME, Tian X, Phinney AL, Manea M, French JE, Lambermon MH, Darabie AA, Brown ME, Janus C, Chishti MA, Horne P, Westaway D, Fraser PE, Mount HT, Przybylski M, St George-Hyslop P (2002) Therapeutically effective antibodies against amyloid- $\beta$ peptide target amyloid- $\beta$ residues $4-10$ and inhibit cytotoxicity and fibrillogenesis. Nat Med 8:1263-1269.

Nicoll JA, Wilkinson D, Holmes C, Steart P, Markham H, Weller RO (2003) Neuropathology of human Alzheimer disease after immunization with amyloid- $\beta$ peptide: a case report. Nat Med 9:448-452.

Oh U, Gupta R, Krakauer JW, Khandji AG, Chin SS, Elkind MSV (2004) Reversible leukoencephalopathy associated with cerebral amyloid angiopathy. Neurology 62:494-497.

Orgogozo JM, Gilman S, Dartigues JF, Laurent B, Puel M, Kirby LC, Jouanny P, Dubois B, Eisner L, Flitman S, Michel BF, Boada M, Frank A, Hock C (2003) Subacute meningoencephalitis in a subset of patients with AD after $A \beta 42$ immunization. Neurology 61:46-54.

Pfeifer M, Boncristiano S, Bondolfi L, Stalder A, Deller T, Staufenbiel M, Mathews PM, Jucker M (2002) Cerebral hemorrhage after passive antibeta amyloid immunotherapy. Science 298:1379.

Rensink AA, de Waal RM, Kremer B, Verbeek MM (2003) Pathogenesis of cerebral amyloid angiopathy. Brain Res Brain Res Rev 43:207-223.

Schenk D, Barbour R, Dunn W, Gordon G, Grajeda H, Guido T, Hu K, Huang J, Johnson-Wood K, Khan K, Kholodenko D, Lee M, Liao Z, Lieberburg I,
Motter R, Mutter L, Soriano F, Shopp G, Vasquez N, Vandevert C, et al. (1999) Immunization with amyloid-beta attenuates Alzheimer-diseaselike pathology in the PDAPP mouse. Nature 400:173-177.

Selkoe DJ (2001) Alzheimer's disease: genes, proteins, and therapy. Physiol Rev 81:741-766.

Shapiro SS, Wilk MB (1965) An analysis of variance test for normality (complete samples). Biometrika 52:591-611.

Spooner ET, Desai RV, Mori C, Leverone JF, Lemere CA (2002) The generation and characterization of potentially therapeutic $A \beta$ antibodies in mice: differences according to strain and immunization protocol. Vaccine 21:290-297.

Sturchler-Pierrat C, Abramowski D, Duke M, Wiederhold KH, Mistl C, Rothacher S, Ledermann B, Burki K, Frey P, Paganetti PA, Waridel C, Calhoun ME, Jucker M, Probst A, Staufenbiel M, Sommer B (1997) Two amyloid precursor protein transgenic mouse models with Alzheimer disease-like pathology. Proc Natl Acad Sci USA 94:13287-13292.

Suzuki N, Iwatsubo T, Odaka A, Ishibashi Y, Kitada C, Ihara Y (1994) High tissue content of soluble beta 1-40 is linked to cerebral amyloid angiopathy. Am J Pathol 145:452-460.

Van Nostrand WE, Melchor JP, Romanov G, Zeigler K, Davis J (2002) Pathogenic effects of cerebral amyloid angiopathy mutations in the amyloid beta-protein precursor. Ann NY Acad Sci 977:258-265.

Vinters HV (1987) Cerebral amyloid angiopathy: a critical review. Stroke 18:311-324.

Walker LC (1997) Animal models of cerebral beta-amyloid angiopathy. Brain Res Brain Res Rev 25:70-84.

Wilcock DM, Rojiani A, Rosenthal A, Alamed J, Wilson D, Wilson N, Freeman MJ, Gordon MN, Morgan D (2004) Passive immunization with anti- $\mathrm{A} \beta$ antibodies reduces amyloid burden while producing a brief activation of microglia in a transgenic mouse model of amyloid deposition. Neurobiol Aging 25:579.

Winkler DT, Bondolfi L, Herzig MC, Jann L, Calhoun ME, Wiederhold KH, Tolnay M, Staufenbiel M, Jucker M (2001) Spontaneous hemorrhagic stroke in a mouse model of cerebral amyloid angiopathy. J Neurosci 21:1619-1627. 